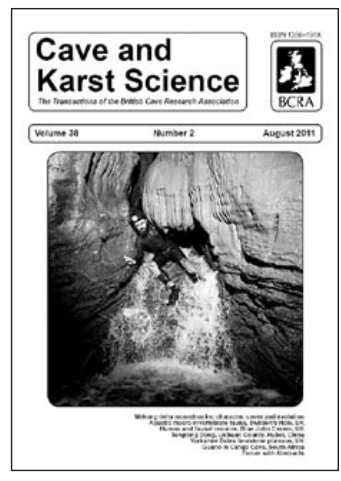

\section{Cave and Karst Science}

Transactions of the British Cave Research Association ISSN 1356-191X

Volume 38, Number 2

\section{Stephen Craven}

Guano in Cango Cave, Oudtshoorn District, South Africa: an attempt at conservation that failed 57-60.

Gerard Campion

Tenglong Dong and the caves of Lichuan County, Hubei, China, 61-64.

Tony Waltham \& Harry Long

Limestone plateaus of the Yorkshire Dales glaciokarst 65-70.

Kevin Kiernan,

Monadnocks of the Mekong delta: character, caves and evolution, 71-80.

Lee Knight

The aquatic macro-invertebrate fauna of Swildon's Hole, Mendip Hills, Somerset, UK, 81-92.

David Nixon

Human and faunal remains from Blue John Cavern, Castleton, Derbyshire, UK, 93-95.

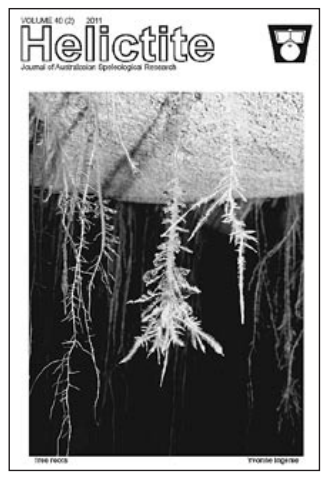

\section{Helictite}

ISSN 0017-9973

Volume 40, Number 2, 2011

Moshumi J. SMITH, Georgette Leah BURNS

Australia's crystalline heritage: issues in cave management at Jenolan Caves, 27-34.

Michael K. TARBURTON

White-rumped Swiftlet Breeding Colony Size and Colony Locations in Samoa, 35-49.

Ken G. GRIMES

Sand structures cemented by focussed flow in dune limestone, Western Australia, 51-54. 


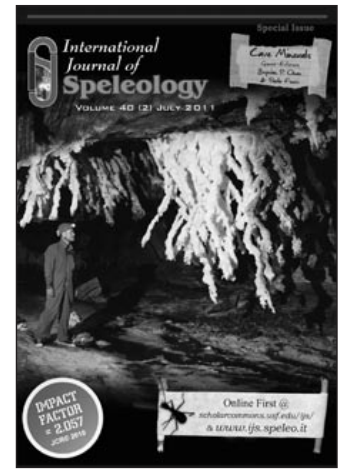

\section{International Journal of Speleology}

ISSN 03926672

Volume 40, Number 2, 2011

Paolo Forti, Bogdan Petroniu Onac

Minerogenetic mechanisms occurring in the cave environment: an overview, 79-98.

Bogdan Petroniu Onac, Herta S. Effenberger, Nathan C. Collins, Joe Kearns, Radu C. Breban.

Revisiting three minerals from Cioclovina Cave (Romania), 99-108.

Robert A.L. Wray.

Alunite formation within silica stalactites from the Sydney Region, South-eastern Australia, 109-116.

Anna Bieniok, Georg Zagler, Uwe Brendel, Franz Neubauer

Speleothems in the dry cave parts of the GamslöcherKolowrat Cave, Untersberg near Salzburg (Austria), 117

-124 .

Giovanni Badino, José Maria Calaforra, Paolo Forti, Paolo Garofalo, Laura Sanna

The present day genesis and evolution of cave minerals inside the Ojo de la Reina Cave (Naica Mine, Mexico), 125-131.
Georgios Lazaridis - Vasilios Melfos - Lambrini Papadopoulou.

The first cave occurrence of orpiment (As2S3) from the sulfuric acid caves of Aghia Paraskevi (Kassandra Peninsula, N. Greece), 133-139.

Michal Filippi, Jiři Bruthans, Lukáš Palatinus, Muhamad Zare, Naser Asadi

Secondary halite deposits in the Iranian salt karst: general description and origin, 141-162.

Fernando Gázquez, José Maria Calaforra, Paolo Forti

Black Mn-Fe crusts as markers of abrupt palaeoenvironmental changes in El Soplao Cave (Cantabria, Spain), 163 -169 .

Tudor Tămaş - Ferenc Kristály - Lucian Barbu-Tudoran Mineralogy of Iza Cave (Rodnei Mountains, N. Romania), 171-179.

Guglielmo Angelo Caddeo, Jo De Waele, Franco Frau, L. Bruce Railsbac

Trace element and stable isotope data from a flowstone in a natural cave of the mining district of SW Sardinia (Italy): evidence for $\mathrm{Zn} 2+-$-induced aragonite precipitation in comparatively wet climatic conditions, 181-190. Szabolcs Leél-Őssy, Gyöngyvér Szanyi, Gergely Surányi Minerals and speleothems of the József-hegy Cave (Budapest, Hungary), 191-203.

Lee J. Florea, Chasity L. Noe-Stinson, Josh Brewer, Rick Fowler, Joe Kearns, Anthony M. Greco

Iron oxide and calcite associated with Leptothrix sp. biofilms within an estavelle in the upper Floridan aquifer, 205-219. 


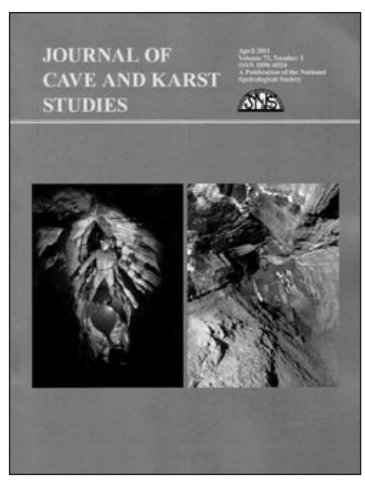

\section{Journal of Cave and Karst Studies Volume 73, Number 1}

Sarita C. Frontana-Uribe, and Vivianne SolI's-Weiss First records of polychaetous annelids from Cenote Aerolito (sinkhole and anchialine cave) in Cozumel Island, Mexico, 1-10.

Marco Gambetta, Egidio Armadillo, Cosmo Carmisciano, Paolo Stefanelli, Luca Cocchi, and Fabio Caratori Tontini Determining geophysical properties of a nearsurface cave through integrated microgravity vertical gradient and electrical resistivity tomography measurements, 11-16. Malcolm S. Field and Guangquan Li

Inversion for the input history of a dye tracing experiment, 17-20.

\section{Joseph W. Dixon}

The role of small caves as bat hibernacula in Iowa, 21-27.

Revaz Djanashvili and Shalva Barjadze

A new species of the genus Plutomurus yossi, 1956 (Collembola, Tomoceridae) from Georgian caves, 28-30.

Ranneveig Øvrevik Skoglund and Stein-Erik Lauritzen Subglacial maze origin in low-dip marble stripe karst: examples from Norway, 31-44.

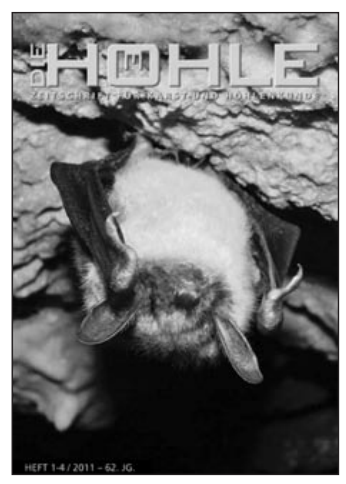

\section{Die Höhle}

Volume 62, Number 1-4

SCIENTIFIC PAPERS

Wagner, $T$.

Datierung fluviatiler Höhlensedimente mittels kosmogener Nuklide am Beispiel des Grazer Berglandes.

Steinwender, C., Plan, L.

Kontaktkarst im Bereich Murursprung-Rosskar (Lungau, Salzburg).

Weißmair, $R$.

Eisdatierung und Eisveränderungen im Kraterschacht (1651/24, Sengsengebirge, Oberösterreich) zwischen 1992 und 2009.

Richter, D. K., Mischel, S., Dorsten, I., Mangini, A., Neuser, R. D., Immenhauser, $A$.

Zerbrochene Höhlensinter und Kryocalcite als Indikatoren für eiszeitlichen Permafrost im HerbstlabyrinthAdventhöhle- System bei Breitscheid-Erdbach (N-Hessen).

Spötl, C., Boch, R., Wolf, A.

Eiszeitliche Klimadynamik im Spiegel eines Stalagmiten aus dem Hölloch (Bayern/Vorarlberg).

Plan, L., De Waele, J.

Folia in der Odelsteinhöhle, Steiermark - Erstnachweis im deutschsprachigen Raum.

\section{EXPLORATION REPORTS}

Behm, $M$.

Verbindung des Unfallschachts mit der Dachstein-Mammuthöhle (1547/9).

Meyer, $U$.

Expedition Vuvu 2010 ins Nakanai-Gebirge auf Neubritannien.

Plan, L., Hölzel, M., Auler, A.

Dokumentation von zwei Quarzithöhlen am Roraima Tepui (Brasilien, Guyana). 